\title{
Virus Transmission Phenotype Is Correlated with Host Adaptation Among Genetically Diverse Populations of the Aphid Schizaphis graminum
}

\author{
Stewart M. Gray, Dawn M. Smith, Lia Barbierri, and John Burd
}

\begin{abstract}
First author: U.S. Department of Agriculture-Agricultural Research Service (USDA-ARS), Plant Protection Research Unit, Ithaca, NY; first, second, and third authors: Department of Plant Pathology, Cornell University, Ithaca, NY; and fourth author: USDA-ARS, Plant Science and Water Conservation Research Laboratory, Stillwater, OK.

Accepted for publication 26 April 2002.
\end{abstract}

\begin{abstract}
Gray, S. M., Smith, D. M., Barbierri, L., and Burd, J. 2002. Virus transmission phenotype is correlated with host adaptation among genetically diverse populations of the aphid Schizaphis graminum. Phytopathology 92:970-975.

Schizaphis graminum is an important insect pest of several grain crops and an efficient vector of cereal-infecting luteoviruses and poleroviruses. We examined the virus transmission characteristics of several distinct populations and various developmental stages of the aphid. Seven wellcharacterized $S$. graminum biotypes maintained at the USDA-ARS laboratory in Stillwater, OK, and two biotypes maintained in New York (one collected in Wisconsin and the other collected in South Carolina) were tested for their ability to transmit five viruses that cause barley yellow dwarf disease (BYD). Four of the Oklahoma biotypes, which do

were efficient vectors of several viruses. The three other Oklahoma biotypes, which do colonize agronomic crops, and the South Carolina biotype, were poor vectors of all five viruses. Thus, the vector specificity long associated with viruses causing BYD is not limited to the level of aphid species; it clearly extends to populations within a single species. $S$. graminum nymphs are reported to be more efficient vectors of Barley yellow dwarf virus (BYDV-SGV) than are adults. This was confirmed only for the Wisconsin biotype, but not for the other eight $S$. graminum biotypes. Thus, there does not appear to be a generalized developmentally regulated barrier to the transmission of BYDV-SGV in S. graminum. Furthermore, the developmentally regulated vector competency observed in the Wisconsin biotype did not extend to other viruses. BYDV-PAV and Cereal yellow $d$ warf virus-RPV were transmitted with similar efficiency by all $S$. graminum biotypes when acquired by nymphs or adults.
\end{abstract} not commonly colonize agronomic crops, and the Wisconsin biotype,
Schizaphis graminum, the Greenbug, is a serious pest of grain crops in many areas of the world and has been the subject of several studies on genetic diversity and adaptability $(25,27)$. Direct feeding injury, exacerbated by the induction of a phytotoxic response of the plant, can significantly reduce crop yield and value (31). S. graminum is also a vector of several plant viruses, including the viruses that cause barley yellow dwarf disease (BYD), the most economically important virus disease of cereal crops worldwide (11).

Multiple distinct populations of $S$. graminum, often referred to as biotypes, have been identified primarily based on their ability to overcome host resistance genes in wheat and sorghum genotypes (25), or on their ability to detoxify insecticides (23). The biotypes can also be differentiated by random amplified polymorphic DNA markers (3) and polymorphisms in ribosomal and mitochondrial DNA sequences $(1,35)$. The origin of the $S$. graminum biotypes is a contested issue, but there is recent evidence that the deployment of resistance genes to $S$. graminum in agronomic crops is not responsible for the generation of new biotypes $(1,20$, $25,35)$. The genetic diversity within $S$. graminum likely existed long before the cultivation of cereals and the deployment of resistance genes. Clonal populations within a biotype can have unique genotypic markers (1) and differ in their phytotoxic reactions on differential host cultivars (35). However, there appears to be very

Corresponding author: S. M. Gray; E-mail address: smg3@ cornell.edu

Publication no. P-2002-0712-01R

This article is in the public domain and not copyrightable. It may be freely reprinted with customary crediting of the source. The American Phytopathological Society, 2002 little genetic diversity within a parthenogenetically propagated clone started from a single $S$. graminum individual (34).

The $S$. graminum biotypes can be divided into two broad categories of host plant preference. The agronomic biotypes are able to overcome resistance genes in sorghum and are commonly found colonizing agronomic crops such as wheat, sorghum, and barley $(25,35)$. Other biotypes, most often found colonizing wild grass species, do not induce a phytotoxic response on resistant sorghums. Recent molecular phylogenetic analyses grouped the described $S$. graminum biotypes into host-related clades $(1,35)$, providing supporting evidence to the theory that $S$. graminum biotypes are host-adapted races (25).

Clonal populations of $S$. graminum can differ in their ability to transmit viruses. Clonal populations from Florida and South Carolina were independently found to be inefficient vectors or unable to vector viruses that cause BYD $(13,29)$, whereas populations collected from several other locations were efficient vectors $(9$, 18). In addition to population differences, the transmission of the SGV strain, and to a lesser extent the PAV strain, of Barley yellow dwarf virus (BYDV-SGV and BYDV-PAV) was developmentally regulated in $S$. graminum (18). First and second instar nymphs were more efficient vectors of BYDV-SGV and BYDV-PAV than were adults, although both nymphs and adults transmitted the related Cereal yellow dwarf virus (CYDV-RPV) with similar efficiency. These findings imply that there is a genetic basis for virus transmission competency in $S$. graminum and that some genetic mechanisms are developmentally regulated. Furthermore, the genetic basis may differ for the two different virus species that cause BYD (i.e., BYDV and CYDV).

The objective of this study was to evaluate the vector competence of numerous $S$. graminum biotypes belonging to both host 
preference groups and to investigate further the developmental regulation of virus transmission in these diverse aphid populations.

\section{MATERIALS AND METHODS}

Aphids and virus. The strains of BYDV (BYDV-PAV, BYDVMAV, BYDV-SGV, and BYDV-RMV) and CYDV-RPV, and their maintenance were previously described (26). Virus-free colonies of aphids were maintained on 'Lud' barley essentially as described by Rochow (30), except the temperature of the rearing rooms was 18 to $20^{\circ} \mathrm{C}$. A population of $S$. graminum collected in 1959 in Wisconsin has been maintained in continuous parthenogenetic culture in Ithaca, NY (29), and is referred to as Sg-NY. The South Carolina population of $S$. graminum ( $\mathrm{Sg}-\mathrm{SC}$ ) was collected in 1995 in Blackwell, SC (13), and has since been maintained in continuous parthenogenetic culture in Ithaca, NY. The B, C, E, F, $\mathrm{G}, \mathrm{H}$, and $\mathrm{K}$ biotypes of $\mathrm{S}$. graminum (Sg-B, Sg-C, Sg-E, Sg-F, $\mathrm{Sg}-\mathrm{G}, \mathrm{Sg}-\mathrm{H}$, and $\mathrm{Sg}-\mathrm{K}$ ), the history of which was described by Porter et al. (25), were obtained from J. Burd, ARS, Stillwater, OK. Colonies of the biotypes obtained from Oklahoma were established on 'Lud' barley and maintained in Ithaca during the course of the experiments. To insure the aphid biotypes were not contaminated with each other during the course of the experiments, each colony was evaluated at the conclusion of the experiments using a set of wheat and barley differentials that distinguish the biotypes (24). The reaction of the Sg-SC population on the set of host differentials was tested for the first time. Twenty-five aphids of various ages were allowed to distribute themselves on three seedlings each of 'Amigo', 'DS28A', 'Largo', and 'Custer' wheat, and 'Wintermalt' and 'Post 90' barley. The plants and aphids were caged and maintained at 18 to $20^{\circ} \mathrm{C}$ under continuous light and observed every 2 days for 14 days. A resistant reaction was typified by the absence of or by minor feeding damage, observed as localized chlorotic regions on the leaves. A susceptible reaction was typified by severe feeding damage (necrosis) that usually led to plant death within 8 to 10 days. Two pots of three plants of each cultivar were used for each aphid biotype, and the complete experiment was repeated twice.

Aphid transmission assays. The virus source tissues were fully expanded leaves detached from plants inoculated 3 to 8 weeks prior. The base of the detached leaf was wrapped in moistened cotton and inserted into a 2-cm-diameter plastic tube so the cotton at the base of the leaf formed a plug at the end of the tube. Adult aphids were collected from a 3-week-old colony and dropped into the tube and allowed to crawl onto the leaf. A foam stopper was used to seal the top end of the tube to prevent aphids from escaping. If adult aphids were the subjects of the assay, they were allowed a $48 \mathrm{~h}$ acquisition access period (AAP). If nymphs were the subjects of the transmission assay, adults were allowed to feed on the leaf and produce young for $24 \mathrm{~h}$ prior to removal. The nymphs were removed $48 \mathrm{~h}$ later; therefore, they were allowed a 48 to $72 \mathrm{~h}$ AAP depending on when they were born. This technique was used to minimize the handling of young aphids, which are easily damaged. At the end of the 48 to $72 \mathrm{~h}$ AAP, a majority of the nymphs had molted to second instars.

The number of aphids transferred from the virus source leaves to recipient noninfected plants ('Coast Black' oat) to determine transmission efficiency varied, but in most experiments, three aphids were transferred to each test plant. Preliminary transmission tests using the Sg-NY and the five virus strains indicated that the transmission efficiency using three aphids per plant was similar to previously reported efficiencies (26). Aphids were allowed a 3 to 5 day inoculation access period (IAP), and the plants were fumigated with DDVP (O,O-dimethyl-O-[2,2-dichlorovinyl] phosphate) in a closed chamber, moved to a greenhouse, and observed for symptom development for 3 to 5 weeks. Virus transmission efficiency was calculated as the percentage of the total number of plants infested with viruliferous aphids that become infected. The binomial transmission efficiency data were transformed as an arcsine square root prior to statistical analysis, and the untransformed data are presented in tables.

Relative virus levels in leaves and aphids. All leaves used as virus source tissue were tested for the presence of virus using a double antibody sandwich enzyme-linked immunosorbent assay (DAS-ELISA) (13). This assay was also used to test any plants from the greenhouse whose infection status was not clear from visual symptoms. In addition, the relative amount of virus antigen in batches of 10 aphids was determined by ELISA. Aphids were stored at $-80^{\circ} \mathrm{C}$ and kept frozen until the addition of $220 \mu \mathrm{l}$ of extraction buffer PBST (phosphate-buffered saline, $\mathrm{pH} 7.4$, containing $0.05 \%$ Tween 20 and $2 \%$ polyvinylpyrrolidone). Duplicate wells of microtiter plates previously coated with the appropriate polyclonal antibody were loaded with $100 \mu \mathrm{l}$ of aphid extract and incubated overnight at $4{ }^{\circ} \mathrm{C}$. The subsequent conjugate and substrate steps were as previously described for plant samples.

Immunocapture-reverse transcription-polymerase chain reaction (IC-RT-PCR) was used to determine the presence of virus in some aphid samples. Aphid homogenates (described previously) were transferred from the microtiter plates, following the overnight incubation, to $500 \mu \mathrm{l}$ thin-walled PCR tubes. The tubes were previously coated with polyclonal antibodies homologous to the virus acquired by the aphids by incubating $50 \mu \mathrm{l}$ of a $1 \mu \mathrm{g} / \mathrm{ml}$ concentration of immunoglobulin $\mathrm{G}$ diluted in carbonate buffer for 2 to $3 \mathrm{~h}$ at $37^{\circ} \mathrm{C}$. Tubes were washed twice with PBST and blocked for 20 min with PBST containing $0.2 \%$ egg albumin. The aphid homogenate $\left(75 \mu \mathrm{l}\right.$ per tube) was incubated overnight at $4^{\circ} \mathrm{C}$, and the tubes were washed four times with PBST and dried. The OneStep PCR kit (Gibco BRL, Gaithersburg, MD) was used to amplify viral sequences. Briefly, $23.5 \mu \mathrm{l}$ of $1 \times$ buffer and $1.5 \mu \mathrm{l}$ (20 pmol) of Lu4 primer (28) were added to each tube and heated to $80^{\circ} \mathrm{C}$ for $5 \mathrm{~min}$ to disrupt the virions and denature the RNA. Twenty-five microliters of a master mix containing 20 pmol of either Lu1 primer (28) or P3 primer (6), $25 \mu \mathrm{M}$ dNTP, enzyme in $1 \times$ buffer were added to each tube. The RT-PCR reaction was performed with a thermal cycler (Thermo Hybaid, Franklin, MA). The RT step was carried out at $50^{\circ} \mathrm{C}$ for 30 min followed by $95^{\circ} \mathrm{C}$ (30 s) and 35 cycles at $95^{\circ} \mathrm{C}(30 \mathrm{~s}), 41^{\circ} \mathrm{C}(45 \mathrm{~s})$, and $72^{\circ} \mathrm{C}(90 \mathrm{~s})$, with a final elongation step of $72^{\circ} \mathrm{C}$ for $5 \mathrm{~min}$. RT-PCR products were separated on a $1.0 \%$ agarose gel, stained with ethidium bromide, and visualized on a UV transilluminator.

\section{RESULTS}

Virus transmission efficiency and host preference in $S$. graminum biotypes. The transmission efficiency of five viruses that cause BYD by the nine different $S$. graminum biotypes tested is summarized in Table 1. In general, the host adaptation of the aphid was correlated with virus transmission competency, although there were differences in transmission efficiency for individual viruses. The $\mathrm{Sg}-\mathrm{C}, \mathrm{Sg}-\mathrm{E}$, and $\mathrm{Sg}-\mathrm{K}$ biotypes are adapted to agronomic crops. The host preference for $\mathrm{Sg}-\mathrm{SC}$ has not been studied, but it was collected from a population colonizing wheat and molecular phylogenetic analysis indicated it was closely related to the agronomic biotypes of $S$. graminum (1). In general, the $\mathrm{Sg}-\mathrm{SC}$ and the agronomic biotypes ( $\mathrm{Sg}-\mathrm{C}, \mathrm{Sg}-\mathrm{E}$, and $\mathrm{Sg}-\mathrm{K}$ ) were inefficient vectors of the five viruses tested (Table 1), particularly BYDV-PAV, BYDV-MAV, and CYDV-RPV. Mean transmission efficiency of BYDV-SGV was slightly higher for Sg-E and $\mathrm{Sg}-\mathrm{K}$ than for $\mathrm{Sg}-\mathrm{SC}$ and $\mathrm{Sg}-\mathrm{C}$, but transmission was not consistent among experiments and differences were not significant $(P=0.05)$. The $\mathrm{Sg}-\mathrm{C}, \mathrm{Sg}-\mathrm{E}$, and $\mathrm{Sg}-\mathrm{K}$ biotypes consistently transmitted BYDV-RMV, but at low levels relative to the other aphid populations tested. Sg-SC transmitted BYDV-RMV infrequently. Feeding damage (i.e., the phytotoxic response) was evident on all virus recipient test plants, and DAS-ELISA analysis of adult aphid 
samples indicated that all biotypes ingested virus regardless of whether they transmitted virus (data not shown). Because brief probing activity does not result in observable feeding damage, these data would indicate that there was not a differential ability of the aphid biotypes to locate and feed on virus-infected phloem tissues.

The Sg-B, Sg-F, Sg-G, and Sg-H biotypes are adapted to wild grasses and tend not to exploit agronomic crops, although $\mathrm{Sg}-\mathrm{B}$ does colonize some wheat varieties, but not sorghum (25). These four biotypes were successfully reared on barley but, in general, the populations developed slower and reached lower population densities than the biotypes adapted to agronomic crops (S. M. Gray, unpublished data) (19). The original host preference of SgNY was not reported at the time of collection in 1958. It has adapted to barley during its 42 years in laboratory culture and it reproduces as well or better on 'Lud' barley than any of the other aphid populations used in this study. Molecular phylogenetic analysis placed the $\mathrm{Sg}-\mathrm{NY}$ (putative biotype A) into a clade containing wild grass biotypes (35). These data, along with virus transmission data (below), suggest the Sg-NY population may be a wild grass biotype.

These five wild grass biotypes were, in general, efficient vectors of the viruses that cause BYD, although the efficiency and specificity of virus transmission varied among specific aphidvirus combinations (Table 1 ). $\mathrm{Sg}-\mathrm{H}$, which may be a separate species $(1,35)$, consistently transmitted all five viruses at high efficiency. The $\mathrm{Sg}-\mathrm{B}, \mathrm{Sg}-\mathrm{F}, \mathrm{Sg}-\mathrm{G}$, and $\mathrm{Sg}-\mathrm{NY}$ biotypes efficiently transmitted BYDV-SGV and BYDV-RMV, but differed in their ability to transmit BYDV-MAV, BYDV-PAV, and CYDV-RPV.

The differential wheat and barley cultivars confirmed that all of the aphid biotypes were maintained as pure cultures throughout the experiments (Table 2). The biotype determination of the SgNY population, based on reactions on differential cultivars, indicated that it is unique from those maintained in Oklahoma (Table 2 ), but similar to the original biotype $A$, which has not been studied for several decades (25). The differential host cultivars did not differentiate the Sg-SC and Sg-NY populations (Table 2).

Developmentally regulated barriers to virus transmission for BYDV-SGV. First and second instar nymphs were reported as the life stages that most efficiently transmitted $S$. graminum-specific isolates of BYDV $(10,18,38)$. To determine if this observation extended to other viruses that cause BYD and to other $S$. graminum populations, transmission efficiencies of BYDV-SGV, BYDVPAV, and CYDV-RPV were compared between adults and first and second instar nymphs. Adult aphids were allowed a $24 \mathrm{~h}$ AAP on infected oat leaves prior to being transferred in groups of three to uninfected plants. The nymphs produced during this $24 \mathrm{~h} \mathrm{AAP}$ were allowed an additional $48 \mathrm{~h}$ AAP prior to being transferred in groups of three to uninfected plants. BYDV-SGV was efficiently transmitted by early instars of Sg-NY, but not by adults (Table 3). Nymphs of Sg-F and Sg-C were better vectors of BYDV-SGV than were adults, although the difference was not as pronounced as with Sg-NY. This developmental effect on transmission efficiency did not extend to BYDV-PAV and CYDV-RPV, which were transmitted at similar efficiencies by nymphs and adults of $\mathrm{Sg}-\mathrm{NY}, \mathrm{Sg}-\mathrm{F}$, and $\mathrm{Sg}-\mathrm{C}$. As expected, Sg-SC did not consistently transmit any of the viruses.

Sg-NY adults can efficiently transmit BYDV-SGV when acquired by first or second instar nymphs. If BYDV-SGV was acquired by first and second instar nymphs, virus was efficiently transmitted throughout their life (Table 4). Adults of Sg-NY and

TABLE 1. Percent transmission of the various luteoviruses that cause Barley yellow dwarf virus (BYDV) and Cereal yellow dwarf virus (CYDV) by different Schizaphis graminum biotypes ${ }^{\mathrm{a}}$

\begin{tabular}{|c|c|c|c|c|c|c|c|c|c|}
\hline \multirow[b]{2}{*}{ Virus } & \multicolumn{4}{|c|}{ Adapted to wild grasses } & \multicolumn{2}{|c|}{ Host adaptation not known } & \multicolumn{3}{|c|}{ Adapted to agronomic crops } \\
\hline & B & $\mathrm{F}$ & G & $\mathrm{H}$ & NY & $\mathrm{SC}$ & $\mathrm{C}$ & $\mathrm{E}$ & $\mathrm{K}$ \\
\hline BYDV-SGV & $\begin{array}{l}78 \pm 11 \\
70 / 90(6)\end{array}$ & $\begin{array}{l}65 \pm 13 \\
52 / 80(5)\end{array}$ & $\begin{array}{l}70 \pm 19 \\
73 / 103(7)\end{array}$ & $\begin{array}{l}85 \pm 13 \\
56 / 65(5)\end{array}$ & $\begin{array}{c}76 \pm 19 \\
121 / 158(10)\end{array}$ & $\begin{array}{l}2 \pm 3 \\
2 / 132(8)\end{array}$ & $\begin{array}{l}7 \pm 7 \\
2 / 30(2)\end{array}$ & $\begin{array}{l}13 \pm 13 \\
10 / 64(4)\end{array}$ & $\begin{array}{l}18 \pm 27 \\
23 / 118(9)\end{array}$ \\
\hline BYDV-PAV & $\begin{array}{l}33 \pm 32 \\
21 / 64(6)\end{array}$ & $\begin{array}{l}29 \pm 11 \\
17 / 58(4)\end{array}$ & $\begin{array}{l}3 \pm 3 \\
2 / 64(4)\end{array}$ & $\begin{array}{l}57 \pm 5 \\
25 / 44(3)\end{array}$ & $\begin{array}{l}52 \pm 24 \\
63 / 120(7)\end{array}$ & $\begin{array}{l}4 \pm 9 \\
4 / 100(6)\end{array}$ & $\begin{array}{l}0 \\
0 / 52(3)\end{array}$ & $\begin{array}{l}0 \\
0 / 68(4)\end{array}$ & $\begin{array}{l}2 \pm 3 \\
1 / 68(4)\end{array}$ \\
\hline BYDV-MAV & $\begin{array}{l}6 \pm 10 \\
4 / 66(4)\end{array}$ & $\begin{array}{l}2 \pm 3 \\
1 / 64(4)\end{array}$ & $\begin{array}{l}30 \pm 13 \\
18 / 62(5)\end{array}$ & $\begin{array}{l}38 \pm 28 \\
27 / 68(4)\end{array}$ & $\begin{array}{l}5 \pm 8 \\
6 / 116(7)\end{array}$ & $\begin{array}{l}0 \\
0 / 100(6)\end{array}$ & $\begin{array}{l}0 \\
0 / 48(3)\end{array}$ & $\begin{array}{l}0 \\
0 / 72(4)\end{array}$ & $\begin{array}{l}0 \\
0 / 72(4)\end{array}$ \\
\hline BYDV-RMV & $\begin{array}{l}48 \pm 18 \\
32 / 68(4)\end{array}$ & $\begin{array}{l}72 \pm 7 \\
49 / 68(4)\end{array}$ & $\begin{array}{l}55 \pm 19 \\
36 / 68(4)\end{array}$ & $\begin{array}{l}68 \pm 19 \\
38 / 52(3)\end{array}$ & $\begin{array}{c}91 \pm 5 \\
119 / 131(7)\end{array}$ & $\begin{array}{l}8 \pm 13 \\
9 / 104(6)\end{array}$ & $\begin{array}{l}39 \pm 3 \\
20 / 51(3)\end{array}$ & $\begin{array}{l}26 \pm 19 \\
17 / 68(4)\end{array}$ & $\begin{array}{l}31 \pm 26 \\
21 / 72(4)\end{array}$ \\
\hline
\end{tabular}

a Mean percent transmission \pm standard deviation calculated as the number of plants infected with virus / the number of plants infested with viruliferous aphids (three aphids per plant), and the number of experimental replicates is in parenthesis.

TABLE 2. Differential capacities of Schizaphis graminum biotypes to colonize wheat and barley cultivars ${ }^{\mathrm{a}}$

\begin{tabular}{|c|c|c|c|c|c|c|c|c|c|c|}
\hline \multirow[b]{2}{*}{ Genotype } & \multirow[b]{2}{*}{ Plant } & \multicolumn{4}{|c|}{ Adapted to wild grasses } & \multicolumn{2}{|c|}{ Host adaptation not known } & \multicolumn{3}{|c|}{ Adapted to agronomic crops } \\
\hline & & B & $\mathrm{F}$ & G & $\mathrm{H}$ & NY & $\mathrm{SC}$ & $\mathrm{C}$ & $\mathrm{E}$ & K \\
\hline Custer & Wheat & $\mathrm{S}$ & $\mathrm{S}$ & $\mathrm{S}$ & $\mathrm{S}$ & S & $\mathrm{S}$ & $\mathrm{S}$ & $\mathrm{S}$ & $\mathrm{S}$ \\
\hline DS28A & Wheat & $\mathrm{S}$ & $\mathrm{R}$ & $\mathrm{S}$ & $\mathrm{S}$ & $\mathrm{S}_{-}$ & $\mathrm{R}-$ & $\mathrm{S}$ & $\mathrm{S}$ & $\mathrm{S}$ \\
\hline Amigo & Wheat & $\mathrm{R}$ & $\mathrm{S}$ & $\mathrm{S}$ & $\mathrm{S}$ & $\mathrm{R}$ & $\mathrm{R}$ & $\mathrm{R}$ & $\mathrm{S}$ & $\mathrm{S}$ \\
\hline CI 17882 & Wheat & $\mathrm{S}$ & $\mathrm{S}$ & $\mathrm{S}$ & $\mathrm{S}$ & $\mathrm{S}$ & $\mathrm{S}$ & $\mathrm{R}$ & $\mathrm{R}$ & $\mathrm{R}$ \\
\hline Largo & Wheat & $\mathrm{S}$ & $\mathrm{S}$ & $\mathrm{S}$ & $\mathrm{R}$ & $S$ & $\mathrm{~S}$ & $\mathrm{R}$ & $\mathrm{R}$ & $\mathrm{R}$ \\
\hline GRS $1201^{b}$ & Wheat & $\mathrm{R}$ & $\mathrm{R}-$ & $\mathrm{R}-$ & $\mathrm{S}$ & $\mathrm{S}$ & $\mathrm{S}$ & $\mathrm{R}$ & $\mathrm{R}$ & $\mathrm{R}$ \\
\hline Wintermalt & Barley & $\mathrm{S}$ & $\mathrm{S}$ & $\mathrm{R}-$ & $\mathrm{S}_{-}$ & $\mathrm{S}$ & $\mathrm{S}$ & $\mathrm{S}$ & $\mathrm{S}$ & $\mathrm{S}$ \\
\hline Post 90 & Barley & $\mathrm{R}$ & $\mathrm{R}$ & $\mathrm{R}$ & $\mathrm{S}_{-}$ & $\mathrm{R}$ & $\mathrm{R}$ & $\mathrm{R}$ & $\mathrm{R}$ & $\mathrm{R}$ \\
\hline
\end{tabular}

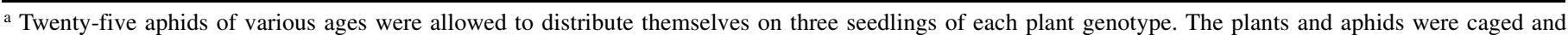
maintained at 18 to $20^{\circ} \mathrm{C}$ under continuous light and observed every 2 days for 14 days. A resistant reaction (R) was typified by the absence of or by minor feeding damage, observed as localized chlorotic regions on the leaves during the 14-day experiment. R- indicates the plants remained relatively free of feeding damage for $>8$ days and then began to show some chlorosis. A susceptible reaction (S) was typified by severe feeding damage (necrosis), which usually led to plant death within 8 to 10 days. S- indicates that severe feeding damage was not observed until after 8 days. Two pots of three plants of each cultivar were used for each aphid biotype, and the complete experiment was repeated twice.

${ }^{\mathrm{b}}$ A susceptible reaction to biotype F was previously reported for GRS 1201 (24). 
Sg-SC were placed on BYDV-infected leaves and allowed to produce nymphs for $24 \mathrm{~h}$ before being removed. The nymphs were allowed an additional $48 \mathrm{~h}$ AAP prior to being transferred (five aphids per plant) to groups of healthy oat seedlings at 48-h intervals. At each transfer, half of the aphids from each treatment were collected and frozen at $-80^{\circ} \mathrm{C}$ in groups of 10 for subsequent analysis of virus antigen titer. For example, following the AAP, 500 nymphs would be transferred to 100 seedlings (five aphids per plant) for a $48 \mathrm{~h}$ IAP. Then, 250 aphids would be collected and transferred to 50 healthy seedlings for another $48 \mathrm{~h}$ IAP, while the remaining 250 aphids were frozen in groups of 10 for ELISA, and so on. Frequently, all five aphids placed on one plant would not survive the $48 \mathrm{~h}$ IAP. The groups of less-than-five aphids were pooled and randomly redistributed into groups of five for the next $48 \mathrm{~h}$ IAP. For $\mathrm{Sg}-\mathrm{NY}$, we were able to follow the transmission efficiency of 15 groups of the same five aphids throughout the experiment, and there was no decrease in the efficiency of transmission over time (day 4, 14/15; day 6, 15/15; day 8, 14/15; and day $10,13 / 15)$. There was no difference in transmission efficiency between the aphid age groups in the total experiment (Table 4). The Sg-SC aphids essentially were unable to transmit BYDVSGV at any age. Our attempt to use DAS-ELISA to quantify the amount of virus retained by the two aphid populations during the course of the experiment was unsuccessful due to the low sensitivity of the assay using the BYDV-SGV-specific antibodies available. The IC-RT-PCR assay did detect virus in aphid samples from both Sg-NY and Sg-SC on each collection date, but provided no quantitative information (data not shown).

\section{DISCUSSION}

The vector specificity long associated with viruses causing BYD (26) is not limited to the level of aphid species; it clearly extends to populations within a single species. Interspecific variation in transmission efficiency of BYDV/CYDV is common in several aphid species that are normally inefficient vectors $(11,21,33)$. In contrast, variability among populations of efficient vectors has been low $(2,14,15,32)$. Guo et al. (14) identified two Sitobion avenae clones that were inefficient vectors $(<20 \%)$ of BYDV-PAV. Habekuss et al. (15) reported significant differences in transmis- sion efficiency of CYDV-RPV by Rhopalosiphum padi, although all clones were consistently able to vector the virus.

Therefore, the significant differences in transmission efficiency among $S$. graminum populations reported here and previously (13, 29) are unusual. Furthermore, the link to host preference is unprecedented. $S$. graminum is most often described as the efficient vector of BYDV-SGV but, as shown here and elsewhere $(4,16,21$, 26 ), this aphid can vector several of the viruses that cause BYD. However, extreme specialization for virus transmission does exist among S. graminum populations, and inefficient vector populations are common and geographically widespread $(13,16,29)$. Therefore, epidemiological studies need to evaluate the population diversity of vector aphids in order to determine their actual contribution to virus spread. For example, in South Carolina $S$. graminum is a consistent early season colonizer of the emerging winter wheat crop, yet $S$. graminum contributes very little to the epidemiology of BYD (5). Previous studies have shown that the Sg-SC clone is but a component of the overall South Carolina S. graminum population, which also contains other clones capable of inefficiently vectoring BYDV-PAV and CYDV-RPV that predomi-

TABLE 4. Ability of two clones of Schizaphis graminum to transmit Barley yellow dwarf virus (BYDV-SGV) during all developmental stages when virus was acquired during the first instar

\begin{tabular}{lccc}
\hline & Developmental & \multicolumn{2}{c}{ Transmission efficiency $^{\mathrm{b}}$} \\
\cline { 3 - 4 } Time after AAP $^{\mathrm{a}}$ & stage & Sg-SC & Sg-NY \\
\hline 1-2 days & Second instar & $2 / 120$ & $101 / 112$ \\
3-4 days & Third instar & $0 / 68$ & $56 / 57$ \\
5-6 days & Fourth instar & $0 / 35$ & $30 / 33$ \\
7-8 days & Adult & $0 / 18$ & $13 / 15$ \\
\hline
\end{tabular}

a Adult aphids were allowed to produce nymphs on BYDV-SGV-infected detached leaves for $24 \mathrm{~h}$. The adults were removed and the nymphs were allowed a further $48 \mathrm{~h}$ acquisition access period (AAP) prior to being moved in groups of five to healthy plants. Following a $48 \mathrm{~h}$ inoculation access period (IAP), the surviving aphids were collected. Half the aphids were redistributed in groups of five to healthy seedlings, and half were frozen in groups of 10 for analysis of virus antigen content. This procedure was repeated for a total of four $48 \mathrm{~h}$ IAPs.

b Numerator is the number of BYDV-SGV-infected plants. Denominator is the number of plants infested with aphids.

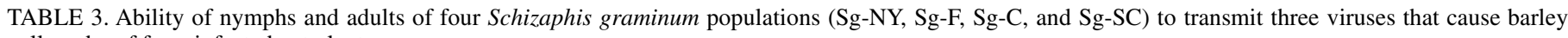
yellow dwarf from infected oat plants

\begin{tabular}{|c|c|c|c|c|}
\hline \multirow[b]{2}{*}{ Aphid clone } & \multirow[b]{2}{*}{ Developmental stage } & \multicolumn{3}{|c|}{ Virus transmission ${ }^{\mathrm{a}}$} \\
\hline & & BYDV-SGV & BYDV-PAV & CYDV-RPV \\
\hline Sg-NY & $\begin{array}{l}\text { Nymph } \\
\text { Adult }\end{array}$ & $\begin{array}{c}62 \pm 22 \% * * \\
4 \pm 6 \%\end{array}$ & $\begin{array}{l}68 \pm 37 \% \text { NS } \\
64 \pm 18 \%\end{array}$ & $\begin{array}{l}92 \pm 10 \%{ }^{\mathrm{NS}} \\
74 \pm 13 \%\end{array}$ \\
\hline $\mathrm{Sg}-\mathrm{F}$ & $\begin{array}{l}\text { Nymph } \\
\text { Adult }\end{array}$ & $\begin{array}{l}73 \pm 19 \% * \\
38 \pm 12 \%\end{array}$ & $\begin{array}{l}71 \pm 24 \% \mathrm{NS} \\
67 \pm 26 \%\end{array}$ & $\begin{array}{l}54 \pm 19 \% \text { NS } \\
54 \pm 7 \%\end{array}$ \\
\hline $\mathrm{Sg}-\mathrm{C}$ & $\begin{array}{l}\text { Nymph } \\
\text { Adult }\end{array}$ & $\begin{array}{c}15 \pm 9 \% \text { NS } \\
5 \pm 8 \%\end{array}$ & $\begin{array}{l}6 \pm 10 \% \text { NS } \\
8 \pm 14 \%\end{array}$ & $\begin{array}{l}17 \pm 10 \% \text { NS } \\
25 \pm 0 \%\end{array}$ \\
\hline $\mathrm{Sg}-\mathrm{SC}$ & $\begin{array}{l}\text { Nymph } \\
\text { Adult }\end{array}$ & $\begin{array}{l}0 \% \text { NS } \\
0 \%\end{array}$ & $\begin{array}{l}0 \%{ }^{\mathrm{NS}} \\
3 \pm 6 \%\end{array}$ & $\begin{array}{l}\mathrm{nt} \\
\mathrm{nt}\end{array}$ \\
\hline \multicolumn{5}{|l|}{ Analysis of variance } \\
\hline Interaction & & $\begin{array}{l}F=7.6 \\
P=0.001\end{array}$ & $\begin{array}{l}F=0.04 \\
P=0.98\end{array}$ & $\begin{array}{l}F=2.12 \\
P=0.16\end{array}$ \\
\hline Developmental stage & & $\begin{array}{l}F=25.1 \\
P<0.001\end{array}$ & $\begin{array}{l}F=0.0 \\
P=0.96\end{array}$ & $\begin{array}{l}F=0.36 \\
P=0.56\end{array}$ \\
\hline Aphid clone & & $\begin{array}{l}F=25.1 \\
P<0.001\end{array}$ & $\begin{array}{l}F=17.31 \\
P<0.001\end{array}$ & $\begin{array}{l}F=45.5 \\
P<0.001\end{array}$ \\
\hline
\end{tabular}

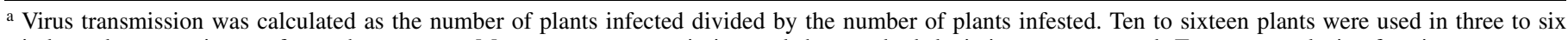
independent experiments for each treatment. Mean percent transmission and the standard deviation are presented. Two-way analysis of variance was performed on the data set for each virus using the arcsine square root transformed transmission data. Three aphids previously given a $24 \mathrm{~h}$ (adults) or 24 to $72 \mathrm{~h}$ (nymphs) acquisition access period on virus-infected tissue were transferred to each seedling for a $96 \mathrm{~h}$ inoculation access period. Values indicate significance levels of pairwise comparisons of transmission efficiency data for nymphs and adults. $* *$ and $*$ indicate significant differences at $P=0.1$ and 0.5 , respectively. $\mathrm{NS}=$ not significant; $\mathrm{nt}=$ not tested . 
nate in South Carolina $(5,13)$. It remains to be determined if only nonvector $S$. graminum clones (i.e., agronomic biotypes) colonize winter wheat in South Carolina. Because BYDV and CYDV are transmitted in a circulative, persistent manner (12), which requires long feeding times, transmission competent wild grass biotypes that are unable to colonize the crop would contribute little to BYD epidemic development.

The correlation of virus transmission phenotype and host adaptation in $S$. graminum populations suggests these traits are genetically linked; although vector competency does vary for individual viruses. Based on phylogenetic analyses, Sg-F, Sg-G, and Sg-NY are closely related $(1,36)$; they are adapted to wild grasses and they share similar vector phenotypes for BYDV-SGV, BYDVRMV, and CYDV-RPV, but differ for BYDV-MAV and BYDVPAV. Sg-B and $\mathrm{Sg}-\mathrm{H}$ are phylogenetically distinct from $\mathrm{Sg}-\mathrm{F}, \mathrm{Sg}-$ $\mathrm{G}$, and $\mathrm{Sg}-\mathrm{NY}$ and from each other, but they share an adaptation to wild grasses. Sg-B is an efficient vector of BYDV-SGV, BYDVRMV, and BYDV-PAV, but not CYDV-RPV, whereas $\mathrm{Sg}-\mathrm{H}$ is an efficient vector of all five viruses tested. The other four populations (Sg-SC, Sg-C, Sg-E, and $\mathrm{Sg}-\mathrm{K}$ ) share a common phylogenetic origin, are all adapted to agronomic hosts, and are all inefficient virus vectors. The various $S$. graminum biotypes are often considered to have arisen as a result of selection pressure exerted by the release of $S$. graminum-resistant wheat and sorghum germ plasm. This dogma has recently been disputed (25), and it was suggested that genetic variation preceded the deployment of resistant germ plasm and arose primarily by sexual reproduction followed by reproductive isolation of clonal populations occupying different ecological niches. $S$. graminum is commonly associated with noncultivated grasses, but has adapted to cultivated monocultures of agronomic grasses. The viruses causing BYD are also abundant in noncultivated grasses, and the aphidvirus associations likely evolved prior to modern crop cultivation. The adaptation of virus from noncultivated to cultivated grass will be dependent upon the vector moving between the two ecosystems and, although the BYD viruses have successfully exploited agronomic crops, perhaps $S$. graminum was not a major factor. For $S$. graminum, the fitness cost of developing on agronomic crops may have come at the expense of virus transmission.

Genetic diversity does exist within biotypes (1), but we only determined the transmission efficiency of one clonal line from each biotype and have not determined if variation in virus transmission phenotype exists among different clonal lineages within a biotype. The holocyclic biotypes (those that reproduce both parthenogenetically and sexually) would be expected to have the greatest genetic diversity either from interclonal mating or from mating with other holocyclic biotypes. Interestingly, the holocyclic biotypes, which include $\mathrm{Sg}-\mathrm{C}, \mathrm{Sg}-\mathrm{E}$, and $\mathrm{Sg}-\mathrm{K}$, were all inefficient vectors of BYDV and CYDV. Does this suggest that virus transmission competence is a recessive trait in S. graminum; a trait that would be more easily retained in anholocyclic (those that only reproduce parthenogenetically) clones such as $\mathrm{Sg}-\mathrm{B}, \mathrm{Sg}-\mathrm{H}$, and Sg-G? Sg-F, an efficient vector, is also holocyclic, but the environmental cues that initiate the switch to sexual reproduction are different and sexual forms are less common (37). This, coupled with the difference in host preference, suggests that matings between $\mathrm{Sg}-\mathrm{F}$ and other holocyclic wild grass biotypes may be infrequent. The genetic basis of virus transmission competence is unknown and the inheritance of vector efficiency has not been studied. It would be interesting to study the inheritance of virus transmission competence in progeny resulting from a cross between an agronomic and a wild grass biotype.

The physical barriers to circulative transmission in the nonvector $S$. graminum biotypes are also unknown, but clearly the data from this study indicates a great deal of aphid biotype-virus species specificity exists. Based on our knowledge of the mechanisms of BYDV and CYDV, aphid species specificity $(7,8,22)$, it is likely that multiple barriers, and therefore, multiple genetic loci, are responsible for preventing BYDV and CYDV transmission by the various $S$. graminum biotypes. Furthermore, the transmission barrier for each nontransmissible virus can differ within a given aphid species and may differ within a given $S$. graminum biotype $(7,8,22)$. Failure to ingest virus was not a barrier to transmission in any $S$. graminum biotype used in this study. All biotypes survived, reproduced, and fed on barley and oat source leaves and the recipient oat plants used in the described experiments. However, it is unknown if similar amounts of virus were acquired into the hemocoel or if the salivary gland barriers prevented or reduced transmission. Genetic loci regulating a virus strain nonspecific mechanism within the circulative transmission pathway may be affected in all agronomic biotypes, whereas loci regulating other virus strain specific transmission mechanisms could differ within and among wild grass and agronomic populations.

Clearly, the developmentally regulated barrier to BYDV transmission reported in $S$. graminum $(10,17,18,29,38)$ is not common to all biotypes. This barrier had inconsistent effects on the transmission of BYDV-PAV (this study, 10) and did not affect the transmission of CYDV-RPV. Zhou and Rochow (38) concluded that BYDV-SGV was unable to navigate salivary gland-associated barriers in adult $\mathrm{Sg}-\mathrm{NY}$ because virus injected directly into the hemocoel was not transmitted. This result, coupled with our finding that virus acquired by first and second instar nymphs can be transmitted when the aphid becomes an adult, suggests that acquired virus moves rapidly to the salivary glands and is slowly released throughout the life of the aphid. Alternatively, virus acquired by nymphs could be modified in some way that allows it to continue to circulate through the salivary glands as the aphid ages. The data generated by this study does not explain any of the potential mechanisms that reduce virus transmission in nonvector $S$. graminum biotypes or in adult aphids, or why wild grass population are better vectors than agronomic populations. However, this work illustrates the genetic and mechanistic diversity of BYDV and CYDV transmission competency within S. graminum biotypes and reveals an experimental system that will be useful in understanding how circulative transmission is regulated by the aphid and the virus.

\section{LITERATURE CITED}

1. Anstead, J. A., Burd, J. D., and Shufran, K. A. 2002. Mitochondrial DNA sequence divergence among Schizaphis graminum (Hemiptera: Aphididae) clones from cultivated and non-cultivated hosts: Haplotype and host associations. Bull. Entomol. Res. 92:17-24.

2. Bencharki, B., El Yamani, M., and Zaoui, D. 2000. Assessment of transmission ability of barley yellow dwarf virus-PAV isolates by different populations of Rhopalosiphum padi and Sitobion avenae. Eur. J. Plant Pathol. 106:455-464.

3. Black, W. C., Duteau, N. M., Puterka, G. J., Nechols, J. R., and Pettorini, J. M. 1992. Use of the random amplified polymorphic DNA-polymerase chain reaction (RAPD-PCR) to detect DNA polymorphisms in aphids (Homoptera: Aphididae). Bull. Entomol. Res. 82:151-159.

4. Brumfield, S. K. Z., Carroll, T. W., and Gray, S. M. 1992. Biological and serological characterization of 3 Montana RMV-like isolates of barley yellow dwarf virus. Plant Dis. 76:33-39.

5. Chapin, J. W., Thomas, J. S., Gray, S. M., Smith, D. M., and Halbert, S. E. 2001. Seasonal abundance of aphids (Homoptera: Aphididae) in wheat and their role as barley yellow dwarf virus vectors in the South Carolina coastal plain. J. Econ. Entomol. 94:410-421.

6. Chay, C. A., Smith, D. M., Vaughan, R., and Gray, S. M. 1996. Diversity among isolates within the PAV serotype of barley yellow dwarf virus. Phytopathology 86:370-377.

7. Gildow, F. E. 1993. Evidence for receptor-mediated endocytosis regulating Luteovirus acquisition by aphids. Phytopathology 83:270-277.

8. Gildow, F. E., and Gray, S. M. 1993. The aphid salivary-gland basal lamina as a selective barrier associated with vector-specific transmission of barley yellow dwarf luteoviruses. Phytopathology 83:1293-1302.

9. Gill, C. C. 1969. Annual variation in strains of barley yellow dwarf virus in Manitoba, and the occurrence of greenbug-specific isolates. Can. J. Bot. 47:1277-1283.

10. Gill, C. C. 1970. Aphid nymphs transmit an isolate of barley yellow dwarf virus more efficiently than do adults. Phytopathology 60:1747- 
1752 .

11. Gray, S. M. 1999. Intraspecific variability of luteovirus transmission within aphid vector populations. Pages 119-123 in: The Luteoviridae. H. G. Smith and H. Barker, eds. CABI Publishing, Wallingford, UK.

12. Gray, S. M., and Banerjee, N. 1999. Mechanisms of arthropod transmission of plant and animal viruses. Microbiol. Mol. Biol. Rev. 63:128-148.

13. Gray, S. M., Chapin, J. W., Smith, D. M., Banerjee, N., and Thomas, J. S. 1998. Barley yellow dwarf luteoviruses and their predominant aphid vectors in winter wheat grown in South Carolina. Plant Dis. 82:13281333.

14. Guo, J. Q., Lapierre, H., and Moreau, J. P. 1997. Clonal variations and virus regulation by aphids in transmission of a French PAV-type isolate of barley yellow dwarf virus. Plant Dis. 81:570-575.

15. Habekuss, A., Leistner, H. U., and Schliephake, E. 1999. Characterization of Rhopalosiphum padi genotypes differing in the geographical origin by transmission efficiency of Barley yellow dwarf viruses and molecular markers. Phytopathol. Z. 106:437-443.

16. Halbert, S. E., Connelly, B. J., Lister, R. M., Klein, R. E., and Bishop, G. W. 1992. Vector specificity of barley yellow dwarf virus serotypes and variants in southwestern Idaho. Ann. Appl. Biol. 121:123-132.

17. Halstead, B. E., and Gill, C. C. 1971. Transmission of barley yellow dwarf virus by different stages of greenbug. Phytopathology 61:749-750.

18. Johnson, R. A., and Rochow, W. F. 1972. An isolate of barley yellow dwarf virus transmitted specifically by Schizaphis graminum. Phytopathology 62:921-925.

19. Kerns, D. L., Puterka, G. J., and Peters, D. C. 1989. Intrinsic rate of increase for greenbug (Homoptera, Aphididae) biotypes E, F, G, and H on small grain and sorghum varieties. Environ. Entomol. 18:1074-1078.

20. Kindler, S. D., and Hays, D. B. 1999. Susceptibility of cool-season grasses to greenbug biotypes. J. Agric. Urban Entomol. 16:235-243.

21. Lucio-Zavaleta, E., Smith, D. M., and Gray, S. M. 2001. Variation in transmission efficiency among Barley yellow dwarf virus-RMV isolates and clones of the normally inefficient aphid vector, Rhopalosiphum padi. Phytopathology 91:792-796.

22. Peiffer, M. L., Gildow, F. E., and Gray, S. M. 1997. Two distinct mechanisms regulate luteovirus transmission efficiency and specificity at the aphid salivary gland. J. Gen. Virol. 78:495-503.

23. Peters, D. C., Wood, E. A., and Starks, K. J. 1975. Insecticide resistance in selections of the greenbug. J. Econ. Entomol. 75:339-340.

24. Porter, D. R., Burd, J. D., Shufran, K. A., and Webster, J. A. 2000. Efficacy of pyramiding greenbug (Homoptera: Aphididae) resistance genes in wheat. J. Econ. Entomol. 93:1315-1318.

25. Porter, D. R., Burd, J. D., Shufran, K. A., Webster, J. A., and Teetes, G. L. 1997. Greenbug (Homoptera: Aphididae) biotypes: Selected by resis- tant cultivars or preadapted opportunists? J. Econ. Entomol. 90:10551065.

26. Power, A. G., and Gray, S. M. 1995. Aphid transmission of barley yellow dwarf viruses: Interactions between viruses, vectors, and host plants. Pages 259-291 in: Barley Yellow Dwarf: 40 Years of Progress. C. J. D'Arcy and P. A. Burnett, eds. The American Phytopathological Society, St. Paul, MN.

27. Puterka, G. J., and Peters, D. C. 1995. Genetics of greenbug (Homoptera: Aphididae) virulence to resistance in sorghum. J. Econ. Entomol. 88:421-429.

28. Robertson, N. L., French, R., and Gray, S. M. 1991. Use of groupspecific primers and the polymerase chain reaction for the detection and identification of luteoviruses. J. Gen. Virol. 72:1473-1478.

29. Rochow, W. F. 1960. Specialization among greenbugs in the transmission of barley yellow dwarf virus. Phytopathology 50:881-884.

30. Rochow, W. F. 1969. Biological properties of four isolates of barley yellow dwarf virus. Phytopathology 59:1580-1589.

31. Ryan, J. D., Morgham, A. T., Richardson, P. E., Johson, R. C., Mort, A. J., and Eikenbary, R. D. 1990. Greenbugs and wheat: A model system for the study of phytotoxic homoptera. Pages 171-186 in: Aphid-Plant Genotype Interactions. R. K. Campbell and R. D. Eikenbary, eds. Elsevier Science, Amsterdam.

32. Sadeghi, E., Dedryver, C. A., and Gauthier, J. P. 1997. Role of acquisition and inoculation time in the expression of clonal variation of BYDVPAV transmission in the aphid species Rhopalosiphum padi. Plant Pathol. 46:502-508.

33. Sadeghi, E., Dedryver, C. A., Riault, G., and Gauthier, J. P. 1997. Variation in transmission of two BYDV-MAV isolates by multiple clones of Rhopalosiphum padi L. Eur. J. Plant Pathol. 103:515-519.

34. Shufran, K. A., Black, W. C., IV, and Margolies, D. C. 1991. DNA fingerprinting to study spatial and temporal distributions of an aphid, Schizaphis graminum. Bull. Entomol. Res. 81:303-314.

35. Shufran, K. A., Burd, J. D., Anstead, J. A., and Lushai, G. 2000. Mitochondrial DNA sequence divergence among greenbug (Homoptera: Aphididae) biotypes: Evidence for host-adapted races. Insect Mol. Biol. 9:179-184.

36. Shufran, K. A., Peters, D. C., and Webster, J. A. 1997. Generation of clonal diversity by sexual reproduction in the greenbug, Schizaphis graminum. Insect Mol. Biol. 6:203-209.

37. Ullah, F., and Peters, D. C. 1996. Sexual reproduction capabilities of greenbugs (Homoptera: Aphididae). J. Kans. Entomol. Soc. 69:153-159.

38. Zhou, G., and Rochow, W. F. 1984. Differences among five stages of Schizaphis graminum in transmission of a barley yellow dwarf luteovirus. Phytopathology 74:1450-1453. 